\title{
Zinc Finger Protein 678
}

National Cancer Institute

\section{Source}

National Cancer Institute. Zinc Finger Protein 678. NCI Thesaurus. Code C102816.

Zinc finger protein 678 (525 aa, $61 \mathrm{kDa}$ ) is encoded by the human ZNF678 gene. This protein may play a role in transcriptional regulation. 